\title{
Physicochemical and Bacteriological Status of Surface Waters and Groundwater in the Selected Catchment Area of the Dunajec River Basin
}

\author{
Aleksandra Nowobilska-Luberda'
}

Department of Sanitary Engineering and Water Management, Faculty of Environmental Engineering and Land Surveying, H. Kołłątaj University of Agriculture in Kraków, Al. Mickiewicza 24/28, 30-059 Kraków, Poland e-mail: olkan321@gmail.com

\begin{abstract}
The aim of the study was to assess the qualitative status of groundwater and surface water abstracted for the needs of customers in the city of Nowy Targ. The assessment was based on the results of physicochemical analyses of 62 water samples taken from the water intake on the Biały Dunajec stream in Szaflary (emergency water intake) and 280 samples taken from 6 active groundwater intakes in Nowy Targ. The basic descriptive statistics of manganese, iron, magnesium, calcium, chlorides, sulphates, phosphates, phosphates, ammonia, nitrites, nitrites, nitrates, chromium, zinc, indicators such as: dissolved oxygen, $\mathrm{BOD}_{5}$, suspension, phenols, $\mathrm{PUR}$, $\mathrm{pH}$, total hardness, alkalinity and number of coli bacteria were determined. The water analyses were performed in the period 2004-2016. Basic descriptive statistics of manganese, iron, magnesium, magnesium, calcium, chlorides, sulphates, phosphates, ammonia, nitrites, nitrates, chromium and zinc ions, as well as such indicators as: dissolved oxygen, $\mathrm{BOD}_{5}$, suspension, phenols, $\mathrm{PEW}, \mathrm{pH}$, total hardness, alkalinity and number of coli bacteria were determined. The quality of the captured waters was classified on the basis of the results obtained, noting that the water from the Biały Dunajec stream corresponds to the A3 purity category due to the microbiological contamination. According to the physicochemical standard, A3 category was also determined on the basis of the phenol concentration, which, however, decreased significantly since 2013, corresponding to category A1. For groundwater, on the other hand, it was established that all analysed indicators corresponded to class I purity grade, i.e. water of a very good quality. The only excess over the values corresponding to this class was recorded for calcium ions, but the classification of water quality has not changed due to the fact that it was caused by natural processes. Taking into account the above-mentioned findings, it was concluded that due to the very good groundwater quality, their intakes should be left as the main source of water for consumers in Nowy Targ, while the surface water intake on the Biały Dunajec stream should be maintained concurrently as an emergency intake.
\end{abstract}

Keywords: groundwater intakes, drinking water, water quality indicators, surface waters, Dunajec catchment area

\section{INTRODUCTION}

Despite the fact that surface water intakes offer the possibility of abstracting large amounts of water using relatively simple technical solutions, their attractiveness is increasingly questioned. The disadvantage of these water intakes is the potential or real threat to the water quality and difficulties in ensuring protection of the intake against pollution. A major problem of these intakes is also the high variability of water qualitative features, e.g. temperature, turbidity or suspension. In turn, natural disasters, such as floods and droughts, have a very negative impact on the quantity of surface water resources. Therefore, more and more urban and industrial agglomerations are building water intakes based on deep wells [Nowobilska-Luberda et al. 2013].

The studies carried out in the United States [Danielle 2014; Lee 2014] have shown that the costs of construction and operation of surface water intakes are several times higher than those of groundwater intakes. In addition, the cost-effectiveness of using surface water for water supply depends on the pollution of these waters and the treatment technology used. It turns out that due to 
the increasing chemical pollution of surface waters, traditional methods of treatment are becoming insufficient.

Therefore, groundwater intakes are an important and alternative solution for providing people with safe and healthy water. These waters have natural protection against pollution and, in most cases, are characterized by good quality parameters. It is generally assumed that ground water does not require treatment before consumption [Thomas et al. 1998]. The main drawbacks of groundwater intakes are limited availability of resources and the technical difficulties connected with their exploitation.

Infiltration water intakes are also a commonly found solution, which unfortunately, due to the increasing pollution of surface waters, are no longer as attractive as they were at the beginning of this century. Hence, the safest intakes of water intended for human consumption are groundwater intakes from deeper hydrogeological structures [Jurel et al. 2013].
The aim of this paper is to analyze the qualitative status of groundwater and surface waters abstracted for the needs of customers of the city of Nowy Targ. On this basis, the information concerning the size and directions of changes in the chemicals of these waters and the occurrence of threats to their quality on a regional scale was obtained.

\section{DESCRIPTION OF RESEARCH}

The research area includes a fragment of the catchment area of the Dunajec River basin located in the city of Nowy Targ. The town has about 34,000 inhabitants [Górka 2009] and is the main administrative, industrial and commercial centre of Podhale. Nowy Targ is located at the intersection of two rivers, i.e. the Czarny and Biały Dunajec rivers, which connect to create the Dunajec River in the north-eastern part of the region (Figure 1).

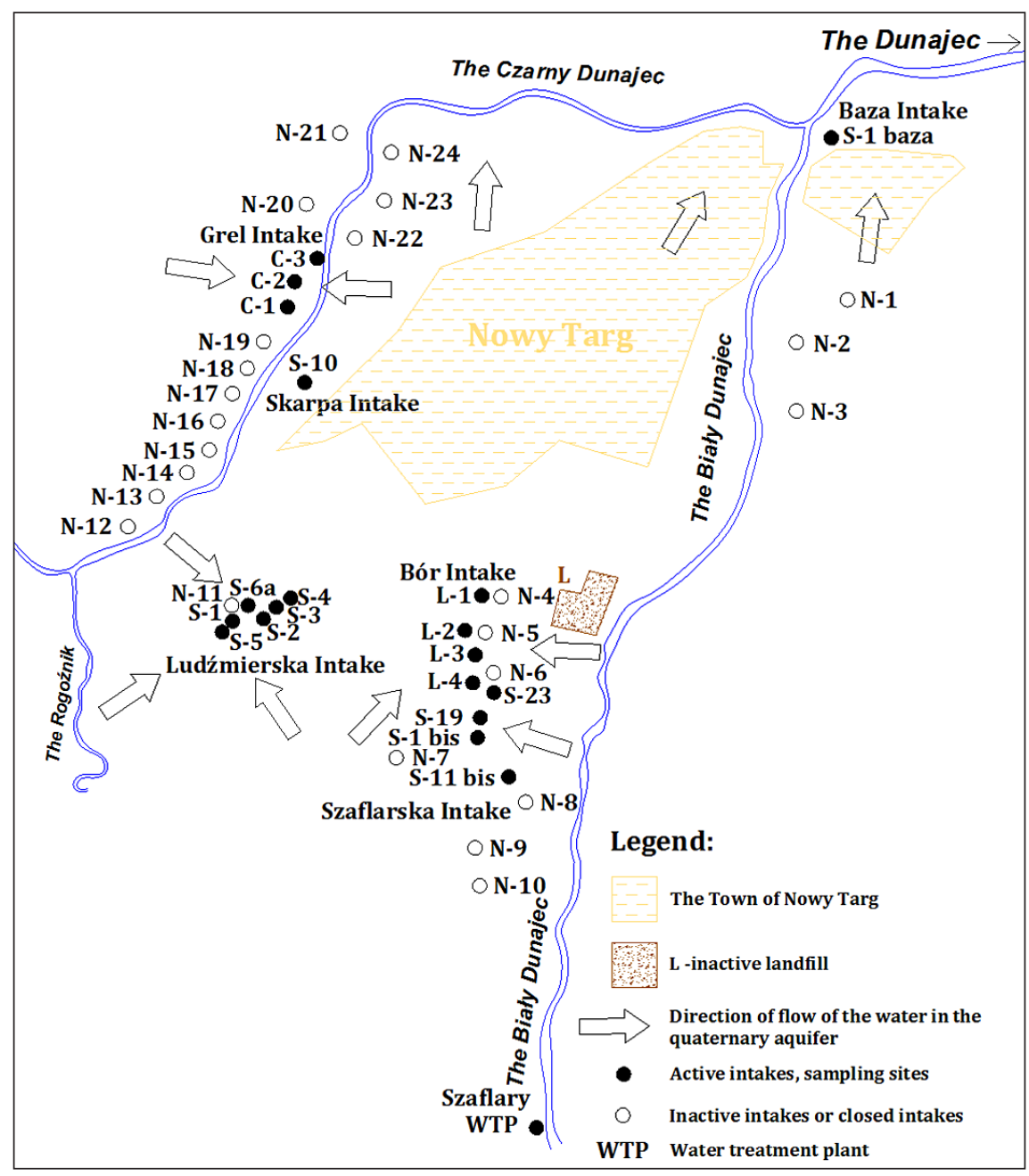

Figure 1. Location of water intakes for Nowy Targ 
For many years, the city used a surface water intake located on the Biały Dunajec river in Szaflary, despite the fact that among the water intakes in the area of research (Figure 1), the largest anthropogenic impact is observed specifically in relation to this river. It is created from the combination of three Tatra mountain streams: Cicha Woda, Strążyski and Bystry.

Since the 1990s, significant structural changes have taken place in the drainage basin of the upper Dunajec River. The most important changes concerned the land use, mainly within the area of agricultural land, the area of which decreased by several percent. In turn, the area of grassland, as well as wastelands and built-up and infrastructural areas, has increased (by ca. 4\%). These transformations are reflected in a clear reduction in the amount of biogenic pollution originating from agriculture, the impact of which on the quality of the upper Dunajec waters is currently negligible [Kopacz and Twardy 2012; Kopacz 2011; Smoroń and Twardy 2006].

At the same time, the concentration of anthropogenic pollution in the waters of the Biały Dunajec river is increasing, which is a result of high density of buildings, unordered wastewater along the stream at stake and a significant number of people arriving here for tourist and leisure purposes [Smoroń and Twardy 2003; 2006].

Concurrently, in contrast to the waters of the Biały Dunajec river, the water quality indicators in the second river of the area concerned, i.e. Czarny Dunajec, point to a small impact of the anthropogenic influence [Cieśla et al. 2006; Synowiec et al. 2009; Smoroń and Twardy 2003]. At the beginning of 2003, the anaerobic bacteria from the Clostridium group, which were hazardous to health, contaminated the waters of the Biały Dunajec river, which led to the necessity of closing the surface water intake in Szaflary, with no alternative water intake for the city. The contamination was caused by 22 illegal sewage discharges, revealed with the use of a thermal imaging camera mounted on a helicopter [Pośpieszałowski et al. 2003]. Therefore, the city authorities decided to base the public water supply on a network of drilled wells, which have been exploited as the main source of water for consumption since 2004. The waters of the Biały Dunajec river are presently abstracted and treated in the water treatment plant in Szaflary only in emergency situations or in the case of insufficient capacity of groundwater intakes.
The discussed area lies within the Orawsko-Nowotarska Basin, where one of the most abundant groundwater reservoirs of the region - MGWB no. 440 [Kleczowski 1998] is located. The thickness of the quaternary water-bearing deposits in which groundwater intakes are made, fluctuates from several meters in the peripheral part of the basin to over 100 metres in its central part (Figure 2). The efficiency of a single well may reach up to $70 \mathrm{~m}^{3} \cdot \mathrm{h}^{-1}$ [Sadurski, 2009].

The groundwater intakes of Nowy Targ are located in the peripheral parts of the city (Figure 1). The intakes of "Skarpa S-10" and "S-1 baza", which are located on the outskirts of the agglomeration, constitute exceptions. The capacity units of the bore wells within the considered area (obtained during the pumping trials) varied widely from 0.26 to $18.5 \mathrm{~m}^{3} \cdot \mathrm{h}^{-1} \cdot \mathrm{m}^{-1}$. That was caused by the different degree of clay compaction in the aquifer. The average unit capacity, calculated for all documented bore wells, amounted to $15 \mathrm{~m}^{3} \cdot \mathrm{h}^{-1} \cdot \mathrm{m}^{-1}$. In the area of Nowy Targ it is possible to obtain from 10 to $30 \mathrm{~m}^{3} \cdot \mathrm{h}^{-1} \cdot \mathrm{m}^{-1}$ of water from a single intake, with depressions ranging from a few to a dozen metres, but where the quaternary clay density increases, the efficiency of wells declines below 10 $\mathrm{m}^{3} \cdot \mathrm{h}^{-1}$ [Górka et al. 2006]. The basic hydrogeological parameters of bore wells in the Nowy Targ area are presented in Table 1.

\section{MATERIAL AND METHODS}

The subject of the research is the diversity of the physicochemical parameters and the bacteriological composition of groundwaters in 19 exploited wells within the 6 groundwater intakes in Nowy Targ and the water abstracted from Biały Dunajec.An analysis of the variability of groundwater and surface water quality was carried out on the basis of the obtained data. Within the scope of the exploitation of wells and intakes on the river, the physicochemical and bacteriological composition of water is monitored ensuring supervision of the water supplied to consumers. The current parameters of the well operations are also monitored, i.e. efficiency and the level of static and dynamic water table. The results of the physicochemical analyses conducted in the study, covers the period 2004-2016. The presented research period is characterised by changes in the law concerning mandatory study areas; therefore, the number of analysis concerning the respective ratings was varied in the respective years. 


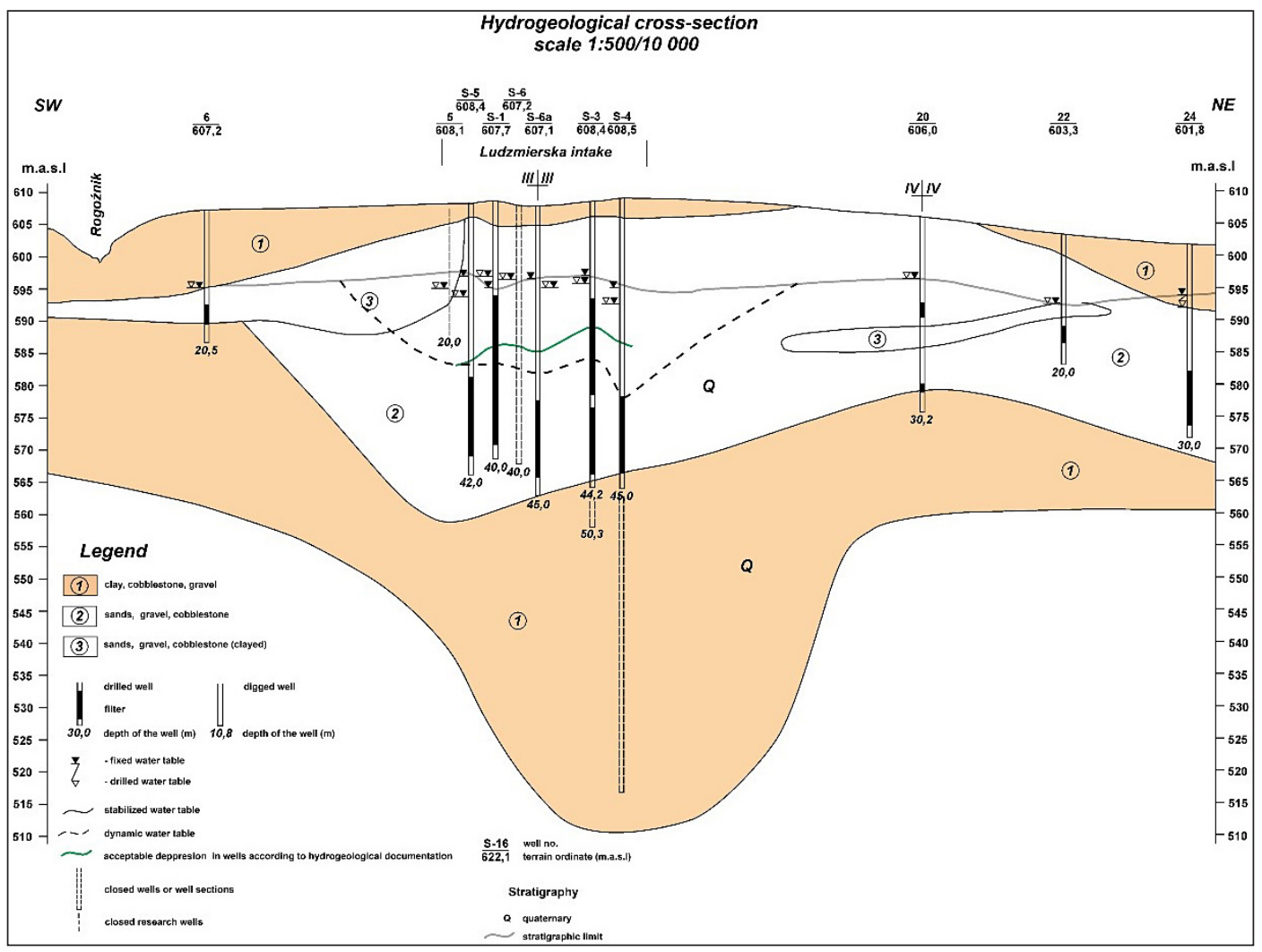

Figure 2. Hydrogeological cross section - „Ludźmierska” intake [Górka 2009]

Table 1. Comparison of the basic parameters of the hydrogeological bore intakes in the Nowy Targ area [Górka 2009]

\begin{tabular}{|c|c|c|c|c|c|c|c|c|}
\hline \multirow{2}{*}{ Intake no: } & \multirow{2}{*}{$\begin{array}{c}\text { Terrain } \\
\text { ordinate }\end{array}$} & \multicolumn{2}{|c|}{ Efficiency } & \multirow{2}{*}{$\begin{array}{c}\text { Thickness of } \\
\text { the aquifer } \\
\text { [m] }\end{array}$} & \multirow{2}{*}{$\begin{array}{l}\text { Depression } \\
{[\mathrm{m}]}\end{array}$} & \multirow{2}{*}{$\begin{array}{l}\text { Well depth } \\
{[\mathrm{m}]}\end{array}$} & \multirow{2}{*}{$\begin{array}{c}\text { Hydraulic } \\
\text { conductivity } \\
\text { indicator } \\
{\left[\mathrm{m}^{2} \cdot \mathrm{d}^{-1}\right]}\end{array}$} & \multirow{2}{*}{$\begin{array}{c}\text { Filtration } \\
\text { factor } \\
{\left[\mathrm{m} \cdot \mathrm{d}^{-1}\right]}\end{array}$} \\
\hline & & $\begin{array}{c}\text { operational } \\
{\left[\mathrm{m}^{3} \cdot \mathrm{h}^{-1}\right]}\end{array}$ & $\begin{array}{l}\text { individual } \\
{\left[\mathrm{m}^{3} \cdot \mathrm{h}^{-1} \cdot \mathrm{m}^{-1}\right]}\end{array}$ & & & & & \\
\hline \multicolumn{9}{|c|}{ "Ludżmierska intake" } \\
\hline S-1 & 607.80 & 45.00 & 4.64 & \begin{tabular}{|l|}
29.00 \\
\end{tabular} & 9.70 & 39.40 & $>232.00$ & 8.00 \\
\hline S-2 & 608.50 & 31.90 & 4.56 & 28.00 & 7.00 & 40.00 & 106.00 & 3.80 \\
\hline S-3 & 608.40 & 31.30 & 4.29 & 31.10 & 7.30 & 44.20 & 185.00 & 5.93 \\
\hline S-4 & 608.50 & 31.00 & 3.52 & 26.40 & 8.80 & 45.00 & 36.00 & 1.38 \\
\hline S-5 & 608.40 & 24.00 & 2.0 & $>27.3$ & 12.00 & 42.00 & $>63.00$ & 2.30 \\
\hline S-6a & 607.10 & 32.00 & 2.86 & \begin{tabular}{|l|}
$>32.2$ \\
\end{tabular} & 11.20 & 45.00 & $>60.00$ & 1.87 \\
\hline \multicolumn{9}{|c|}{ "Szaflarska intake" } \\
\hline S-1bis & 616.00 & 22.00 & 5.80 & \begin{tabular}{|l|}
7.40 \\
\end{tabular} & 3.80 & 21.00 & 138.00 & 18.70 \\
\hline S-11bis & 615.50 & 19.00 & 3.92 & 9.00 & 4.85 & 20.00 & 103.00 & 11.4 \\
\hline S-19 & 617.20 & 50.60 & 12.00 & 10.00 & 4.20 & 27.50 & 640.00 & 64.00 \\
\hline S-23 & 616.00 & 31.40 & 6.54 & 7.40 & 4.80 & 24.00 & 463 & 62.50 \\
\hline \multicolumn{9}{|c|}{ "Grel intake" } \\
\hline $\mathrm{C}-1$ & 590.00 & 20.60 & 3.00 & 22.00 & 6.80 & 27.20 & 138.00 & 6.25 \\
\hline C-2 & 589.70 & 13.50 & 1.50 & 23.00 & 9.20 & 28.50 & 93.00 & 4.02 \\
\hline C-3 & 589.80 & 11.00 & 2.11 & 23.50 & 5.20 & 30.00 & 108.00 & 4.62 \\
\hline \multicolumn{9}{|c|}{ "Skarpa intake" } \\
\hline S-10 & 600.90 & 28.80 & 7.20 & \begin{tabular}{|l|}
24.20 \\
\end{tabular} & 4.00 & 38.50 & 204.00 & 8.45 \\
\hline \multicolumn{9}{|c|}{ "Baza intake" } \\
\hline S-1baza & 581.90 & 5.80 & 2.32 & \begin{tabular}{|l|}
13.00 \\
\end{tabular} & 2.50 & 23.00 & 44.00 & 3.40 \\
\hline \multicolumn{9}{|c|}{ "Bór intake" } \\
\hline $\mathrm{L}-1$ & 611.70 & 26.70 & 6.17 & 6.50 & 4.65 & 25.00 & 172.00 & 26.50 \\
\hline $\mathrm{L}-2$ & 612.80 & 28.00 & 7.57 & 6.70 & 3.70 & 25.00 & 255.00 & 38.10 \\
\hline $\mathrm{L}-3$ & 614.20 & 29.00 & 7.84 & 7.50 & 3.70 & 25.00 & 282.00 & 37.60 \\
\hline $\mathrm{L}-4$ & 615.30 & 28.80 & 12.00 & 8.20 & 2.40 & 25.00 & 528.00 & 64.40 \\
\hline
\end{tabular}


The water quality assessment was conducted on the basis of the materials obtained from the monitoring carried out at the control and measurement points, the location of which is important for the reliable assessment of the quality of the tested waters, as well as the waters with the highest repeatability of measurements in the mentioned research period. The following quality indicators were taken into account: temperature, smell, taste, colour, turbidity, electrolytic conductivity, $\mathrm{pH}$ value, oxidability, total and carbonate hardness, alkalinity to methyl orange, manganese, iron, magnesium, calcium, chloride, sulfates, phosphates, ammonia, nitrites, nitrates, COD, ammonia, chromium, zinc, dissolved oxygen, $\mathrm{BOD}_{5}$, suspension, phenols, total solids and the number of $E$. Coli bacteria.

The main source of information involved the reports of the physicochemical tests of water samples made by the Laboratory of the Municipal Water Supply and Sewerage Board in Nowy Targ and the Regional Sanitary-Epidemiological Station. The basic statistical characteristics of individual indicators were defined in the research. During the research period, 62 samples of water from surface intakes and 280 samples of water from underground intakes were drawn. The analyses of the samples were conducted according to the reference methods included in the regulations of the Minister of the Environment, which were in force during the research period.

\section{RESULTS AND DISCUSSION}

Pollution and degradation of the water environment are mainly caused by the industrial and municipal sewage from human activity. Urbanization, intensive agricultural production and industrial activity in the catchment area of the reservoir or a river course, have a significant impact on the water quality. Intensively used agricultural catchment and rural areas, are considered to be the main sources of pollution and loss of surface water biodiversity [Durkowski and Woroniecki 2001].

In the case of Podhale, the pollution caused by the growing tourist traffic in areas with disorganised sewage management has been the main threat to the soils and waters of the region [Małecki and Porowska 2005; Smoroń and Twardy 2006].

The catchment area of the Biały Dunajec river is one of the areas with the highest intensity of tourist traffic in the Polish Carpathians. Therefore, there is a close relationship between the tourist and holiday traffic and surface water quality in the catchment area of this river. Water quality studies conducted in Szaflary show that the values of pollution indicators fluctuate depending on the quality of municipal wastewater treated to various degrees which is discharged into the Biały Dunajec river and its tributaries. The quality of groundwater and surface water is also significantly affected by the pollution that penetrates these waters as a result of surface run-offs from municipal and agricultural areas without sewage system [Smoroń and Twardy 2003; Smoroń and Kuźniar 2006].

Kopacz and Twardy [2012] noticed that in times of increased tourist traffic, there may be more wastewater than expected, posing problems for the wastewater treatment plants with lower capacity. Increased discharge of insufficiently treated wastewater to the sewage storage tank may also be caused by temporary failures of treatment systems or high atmospheric precipitation, which significantly increase the volume of sewage influent into the sewage system, thereby preventing their effective treatment due to the limited capacity of the sewage treatment plant. As the studies of Smoron and Twardy [2006] show, the above-mentioned arguments are one of the main causes of water pollution in the Bialy Dunajec catchment.

Due to the fact that the waters of the Biały Dunajec river are used to supply people with water for human consumption, their quality has been assessed in relation to the provisions of the relevant Regulation of the Minister of the Environment [Regulation 2002]. As Table 2 shows, in terms of the physicochemical indicators, the water of the Biały Dunajec at the level of the Szaflary intake corresponds to A1 category, i.e. water requiring simple physical treatment, in particular filing and disinfection. The values of these indicators show insignificant influence of anthropogenic interactions. The water analyses carried out in the period 2004-2016 have proven that the degrading indicators were bacteriological factors: total number of coli bacteria, the values of which indicate, as mentioned earlier, a significant seasonal influence of anthropological pressure. According to a survey by Cieśla et al. [2006] and Synowiec et al. [2009], in the waters of Biały Dunajec tested in the Zakopane-Szaflary section of the Biały Dunajec river, a significant increase in the value of bac- 
Table 2. Descriptive statistics of the Biały Dunajec water quality indicators abstracted in Nowy Targ in years 2004-2016

\begin{tabular}{|c|c|c|c|c|c|c|c|c|}
\hline \multirow{2}{*}{$\begin{array}{l}\text { Water quality } \\
\text { indicator }\end{array}$} & \multirow{2}{*}{ Unit } & \multicolumn{6}{|c|}{ Descriptive statistics } & \multirow{2}{*}{$\begin{array}{l}\text { Water quality } \\
\text { category }\end{array}$} \\
\hline & & average & median & minimum & maximum & $\begin{array}{l}\text { Standard } \\
\text { deviation }\end{array}$ & $\begin{array}{l}\text { Coefficient of } \\
\text { variation [\%] }\end{array}$ & \\
\hline $\begin{array}{l}\text { Electrolytic } \\
\text { conductivity }\end{array}$ & $\mu S$ & 503.70 & 350.00 & 233.00 & 2500.00 & 492.40 & 97.80 & $\mathrm{~A} 1$ \\
\hline $\begin{array}{l}\text { Water pH } \\
\text { condition }\end{array}$ & - & 8.00 & 8.10 & 6.60 & 8.80 & 0.40 & 5.50 & $\mathrm{~A} 1$ \\
\hline Chlorides & $\mathrm{mg} \cdot \mathrm{dm}^{-3}$ & 19.80 & 13.00 & 5.00 & 250.00 & 35.90 & 181.70 & $\mathrm{~A} 1$ \\
\hline Sulphates & $\mathrm{mg} \cdot \mathrm{dm}^{-3}$ & 25.70 & 21.00 & 2.30 & 210.00 & 36.10 & 140.50 & $\mathrm{~A} 1$ \\
\hline Total iron & $\mathrm{mg} \cdot \mathrm{dm}^{-3}$ & 0.13 & 0.10 & 0.01 & 0.30 & 0.09 & 67.50 & $\mathrm{~A} 1$ \\
\hline Manganese & $\mathrm{mg} \cdot \mathrm{dm}^{-3}$ & 0.03 & 0.03 & 0.01 & 0.05 & 0.01 & 34.90 & $\mathrm{~A} 1$ \\
\hline Phosphates & $\mathrm{mg} \cdot \mathrm{dm}^{-3}$ & 0.23 & 0.12 & 0.01 & 2.26 & 0.36 & 154.70 & $\mathrm{~A} 1$ \\
\hline COD & $\mathrm{mg} \cdot \mathrm{dm}^{-3}$ & 5.30 & 4.30 & 0.70 & 27.20 & 4.80 & 90.70 & $\mathrm{~A} 1$ \\
\hline Ammonia & $\mathrm{mg} \cdot \mathrm{dm}^{-3}$ & 0.25 & 0.11 & 0.00 & 1500.00 & 0.31 & 122.20 & $\mathrm{~A} 1$ \\
\hline Nitrates & $\mathrm{mg} \cdot \mathrm{dm}^{-3}$ & 6.99 & 5.40 & 2.00 & 50.00 & 7.00 & 100.10 & $\mathrm{~A} 1$ \\
\hline Chromium & $\mathrm{mg} \cdot \mathrm{dm}^{-3}$ & 0.02 & 0.02 & 0.00 & 0.04 & 0.01 & 73.10 & $\mathrm{~A} 1$ \\
\hline Zinc & $\mathrm{mg} \cdot \mathrm{dm}^{-3}$ & 0.09 & 0.03 & 0.00 & 0.20 & 0.09 & 0.00 & $\mathrm{~A} 1$ \\
\hline Dissolved oxygen & $\mathrm{mg} \cdot \mathrm{dm}^{-3}$ & 83.20 & 81.50 & 52.00 & 112.00 & 20.70 & 24.90 & $\mathrm{~A} 1$ \\
\hline BOD5 & $\mathrm{mg} \cdot \mathrm{dm}^{-3}$ & 2.45 & 2.30 & 0.80 & 5.80 & 1.13 & 46.40 & $\mathrm{~A} 1$ \\
\hline Total suspension & $\mathrm{mg} \cdot \mathrm{dm}^{-3}$ & 12.30 & 6.00 & 2.00 & 55.20 & 15.10 & 123.10 & $\mathrm{~A} 1$ \\
\hline Phenols & $\mathrm{mg} \cdot \mathrm{dm}^{-3}$ & 0.04 & 0.02 & 0.00 & 0.30 & 0.07 & 179.80 & $\mathrm{~A} 3 / \mathrm{A} 1^{*}$ \\
\hline Total hardness & $\mathrm{mg} \cdot \mathrm{dm}^{-3}$ & 3.26 & 3.19 & 2.26 & 5.32 & 0.89 & 27.50 & $\mathrm{~A} 1$ \\
\hline Alkalinity & $\mathrm{mval} \cdot \mathrm{dm}^{-3}$ & 2.60 & 2.63 & 1.40 & 4.30 & 0.91 & 35.20 & A1 \\
\hline Calcium & $\mathrm{mg} \cdot \mathrm{dm}^{-3}$ & 78.60 & 54.10 & 43.60 & 327.00 & 82.70 & 105.20 & $\mathrm{~A} 1$ \\
\hline Magnesium & $\mathrm{mg} \cdot \mathrm{dm}^{-3}$ & 31.90 & 5.80 & 2.30 & 327.00 & 93.00 & 291.20 & $\mathrm{~A} 1$ \\
\hline $\begin{array}{l}\text { Number of coli } \\
\text { bacteria }\end{array}$ & units $/ 100 \mathrm{~cm}^{3}$ & 24254.5 & 24000.00 & 2400.00 & 70000.00 & 17459.10 & 72 & A3 \\
\hline
\end{tabular}

* Since 2013 onwards, phenol concentrations correspond to A1 category.

teriological factors is observed in February and August, i.e. in the periods of the greatest increase in the tourist traffic related to winter break and the holiday period.

The Regulation of the Minister of the Environment on criteria and method of assessing the condition of groundwater bodies in relation to the limit values of physicochemical elements [Ordnance 2015] was used in the evaluation of groundwater quality abstracted for the needs of customers in Nowy Targ. On its basis, it has been found that these waters correspond to the first class of purity (very good quality waters), which means that the values of physicochemical elements are formed only as a result of natural processes occurring in groundwater, are within the range of hydrogeochemical background and do not indicate the influence of human activity (Table 3). It should be noted that the average values given in the table are the arithmetic mean values of the concentrations of the tested indicators obtained from the whole test period at all measurement points in total.
The only indicator with the value corresponding to Class II of purity was calcium. It is a natural element occurring in groundwater, mainly as a result of dissolving minerals of the rock matrix of the aquifer. However, since the Regulation allows limits for physicochemical elements to be exceeded (without changing the water quality classification) when it is caused by natural processes, the groundwater in Nowy Targ was classified at level I of the purity class.

Characterizing the groundwater abstracted in Nowy Targ, it should be mentioned that high conductivity values indicate an increased mineralisation of water, qualifying it for freshwater - acratopegae. The $\mathrm{pH}$ value, on the other hand, allows the analysed waters to be classified as very low alkaline waters. While analysing the chloride concentrations, it was found that the highest values (above $100 \mathrm{mg} \cdot \mathrm{dm}^{-1}$ ) were found only in the $\mathrm{L}^{-1}$ well of the Bór intake, which may result from the effect of liquidated landfill on these waters. Bacteriological indicators of the captured waters in all wells are of no concern, although average 
Table 3. Descriptive statistics of groundwater quality indicators in Nowy Targ in years 2004-2016

\begin{tabular}{|l|c|c|c|c|c|c|c|c|}
\hline \multirow{2}{*}{\begin{tabular}{c}
\multirow{2}{*}{$\begin{array}{c}\text { Water quality } \\
\text { indicator }\end{array}$} \\
\cline { 3 - 10 }
\end{tabular}} & Unit & average & median & minimum & maximum & $\begin{array}{c}\text { Standard } \\
\text { deviation }\end{array}$ & $\begin{array}{c}\text { Coefficient of } \\
\text { variation }[\%]\end{array}$ & $\begin{array}{c}\text { Water quality } \\
\text { category }\end{array}$ \\
\hline $\begin{array}{l}\text { Electrolytic } \\
\text { conductivity }\end{array}$ & $\mu \mathrm{S}$ & 590.00 & 642.50 & 181.00 & 1973.00 & 241.60 & 40.90 & $\mathrm{I}$ \\
\hline Water pH condition & - & 7.40 & 7.40 & 6.60 & 8.40 & 0.30 & 3.60 & $\mathrm{I}$ \\
\hline Chlorides & $\mathrm{mg} \cdot \mathrm{dm}^{-3}$ & 38.70 & 29.00 & 1.90 & 390.00 & 41.50 & 107.40 & $\mathrm{I}$ \\
\hline Sulphates & $\mathrm{mg} \cdot \mathrm{dm}^{-3}$ & 28.20 & 40.00 & 0.10 & 40.00 & 17.30 & 61.40 & $\mathrm{I}$ \\
\hline Manganese & $\mathrm{mg} \cdot \mathrm{dm}^{-3}$ & 0.02 & 0.02 & 0.00 & 0.040 & 0.008 & 43.2 & $\mathrm{I}$ \\
\hline Phosphates & $\mathrm{mg} \cdot \mathrm{dm}^{-3}$ & 0.17 & 0.15 & 0.02 & 0.38 & 0.10 & 61.00 & $\mathrm{I}$ \\
\hline Ammonia & $\mathrm{mg} \cdot \mathrm{dm}^{-3}$ & 0.05 & 0.03 & 0.01 & 0.14 & 0.04 & 75.20 & $\mathrm{I}$ \\
\hline Nitrates & $\mathrm{mg} \cdot \mathrm{dm}^{-3}$ & 9.44 & 10.00 & 0.04 & 22.00 & 5.20 & 55.20 & $\mathrm{I}$ \\
\hline Calcium & $\mathrm{mg} \cdot \mathrm{dm}^{-3}$ & 78.50 & 78.60 & 3.10 & 212.00 & 33.00 & 42.10 & $\mathrm{I}$ \\
\hline Magnesium & $\mathrm{mg} \cdot \mathrm{dm}^{-3}$ & 14.60 & 14.00 & 2.80 & 40.70 & 7.90 & 54.30 & $\mathrm{I}$ \\
\hline Nitrites & $\mathrm{mg} \cdot \mathrm{dm}^{-3}$ & 0.03 & 0.03 & 0.00 & 0.04 & 0.01 & 48.90 & $\mathrm{I}$ \\
\hline Phosphates & $\mathrm{mg} \cdot \mathrm{dm}^{-3}$ & 0.00 & 0.08 & 0.01 & 0.19 & 0.07 & 66.70 & $\mathrm{I}$ \\
\hline $\begin{array}{l}\text { Number of coli } \\
\text { bacteria }\end{array}$ & $\mathrm{units} / 100 \mathrm{~cm}^{3}$ & 0 & 0 & 0 & 0 & 0 & - & $\mathrm{n} / \mathrm{a}$ \\
\hline
\end{tabular}

$\mathrm{n} / \mathrm{a}$ - indicator not included in the Regulation.

nitrate concentrations may indicate that the bacteriological contamination of waters is spatially and temporally distant.

\section{CONCLUSIONS}

1. On the basis of the values of physicochemical indicators of water quality it was found that the waters of the Biały Dunajec stream at the level of the Szaflary intake were of A3 category until 2013, and due to the subsequent significant reduction of volatile phenols concentration, these waters were qualified to the A1 category.

2. The water quality of the surface intake waters was degraded by bacteriological contaminants, described by the total number of the coliform bacterias, eventually allowing to classify these waters as A3 category.

3. The physical, chemical and bacteriological condition of the abstracted groundwater in Nowy Targ raises no objections.

4. Due to the very good groundwater quality, their intakes should be left as the main source of water for the customers in Nowy Targ, keeping in mind the constant monitoring ensuring the rapid detection of potential threats.

5. In view of the periodical demand and for water in Nowy Targ that exceeds the capacity of groundwater intakes, the surface intake on the
Biały Dunajec stream should be kept in place, ensuring a highly efficient process of disinfection of the water supplied to the customers.

6. In order to improve the bacteriological quality of the waters of the Biały Dunajec River, it is necessary to undertake comprehensive measures aimed at the ordination of wastewater management in the entire catchment area.

\section{REFERENCES}

1. Cieśla G., Łęczycka D., Tyrkiel-Cebula L. 2006. Assesment of quality of surface waters flowing through Nowy Targ municipality on the basis of research conducted in 2005 (in Polish). Provincial Inspectorate of Environmental Protection in Cracow.

2. Durkowski T., Woroniecki T. 2001. The quality of surface waters in the rural areas of West Pomerania (in Polish). Zeszyty Problemowe Postępów Nauk Rolniczych, 476, 365-371.

3. Górka J., Reczek D. 2006. Project of geological works to document the hydrogeological conditions of the groundwater reservoir Nowy Targ Fossil Valley (GZWP 440) (in Polish). Cracovian Geological Company „ProGeo”, Cracow.

4. Górka J. 2009. The cocncept of the target $350 \mathrm{~m}^{3} / \mathrm{h}$ of groudwater to the city of Nowy Targ (in Polish). Cracovian Geological Company „ProGeo”, Cracow.

5. Jurel R., Singh Raj, Jurel Sunit, Singh R. 2013. Infiltration Galleries: A solution to drinking water supply for urban areas near rivers. IOSR Journal of 
Mechanical and Civil Engineering (IOSR-JMCE), 5(3), 29-33.

6. Kalisek D. 2014. Is it time for Texas to welcome ASR? Texas weights the costs and advantages of aquifer storage and recovery. Texas Water Resources Institute, 9(1), 10-13.

7. Kleczkowski A.S. (Ed.), 1990. Map of the major Underground Water Reservoris (GZWP) in Poland, requiring special protection, together with explanations (in Polish). Publishing Company of AGH University of Science and Technology, Cracow.

8. Kopacz M. 2011. The variability of the load of fertilizers on Carpathian agricultular areas in the context of strutural and spatial transformations (in Polish). Water-Environment-Rural Areas. Scientific Discussion and Monographs, No 31, pp. 122.

9. Kopacz M., Twardy S. 2012. Water and wasterwater management in the Upper Dunajec catchment based on socio-economic and structural changes and surface water quality (in Polish). Water-Environment-Rural Areas. T.12, z.3, (39), 103-121.

10. Lee L. 2014. Under ground and under scrutiny. A changing state increasingly turns to groundwater. Texas Water Resources Institute, 9 (1), 2-4.

11. Małecki J., Porowska D. 2005. Groundwater chemistry changes related to economic and tourism impact in the Zakopane region. Polish Geological Institute Special Papers, 18, 52-61.

12. Nowobilska-Luberda A., Nowobilska E., Satora S., 2013. Intakes and underground waters used for suplying the city of Nowy Targ (in Polish). Acta Sci. Pol., Formatio Circumiectus 12(3) 2013, 81-91.

13. Pospieszałowski W., Synowiec K., Cieśla G. 2003. Pollution of White Dunajec waters based on monitoring studies (in Polish). Provincial Inspectorate of Environmental Protection in Cracow.
14. Regulation of the Minister of Environment of November 27,2002 , regarding the requirements relating to the methods of analysis and evaluation and other quality assurances conditions to ensure the water is safe for human consumption .Dz.U. of December 9, 2002 (Journal of Laws).

15. Regulation of the Minister of Environment of December 21, 2015, regarding criterias and methods of assessment of the condition of the groundwater bodies. Dz.U. 2016 item 85. (Journal of Laws).

16. Sadurski A., 2009. evaulation of quantitative, qualitative condition and defining pollution trends in the undrergrounds waters of the dunajec river draingage basin with the use of research conducted within implementation of the PL 0302 Project. Nicolas Copernicus University in Toruń, Warsaw - Torun.

17. Smoron S., Twardy S., 2003. The influence of the variable increase in holiday and tourism traffic on the quality of the waters of the White and Black Dunajec rivers (in Polish). Water-EnvironmentRural Areas. T.3, z.2 (8), 91-102.

18. Smoroń S,. Twardy S. 2006. Concentrations and loads of $\mathrm{N}-\mathrm{NO}_{3}, \mathrm{~N}-\mathrm{NH}_{4}, \mathrm{PO}_{4}$ and $\mathrm{BOD}_{5}$ in waters of the upper Dunajec (in the years 1985-1998). Journal of Water and Land Development, 10, 151-162.

19. Smoroń S., Kużniar A., 2006. The seasonal changes of a surface water quality in the tourist areas of the Podhale (the westerm Carpathians). Polish Journal of Environmental Study, 15(5c), 90-93.

20. Synowiec K., Główak A., Cieśla G., Raczek T., 2009. Assesment of surface water quality in Malopolskie voivodship in 2008 (in Polish). Provincial Inspectorate of Environmental Protection in Cracow.

21. Winter T.C., Harvey J.W., Franke O.L., Alley W.M., 1998. Ground water and surface water a single resource. U.S. Geological Survey Circular 1139, 79. 